Ethiopian Journal of Environmental Studies \& Management 10(2): 208 - 218, 2017.

ISSN:1998-0507

doi: http://dx.doi.org/10.4314/ejesm.v10i2.7

Submitted: November 16, 2016

Accepted: March 15, 2017

\title{
AGRICULTURAL CREDIT GUARANTEE SCHEME AND FOOD SECURITY IN NIGERIA
}

*IJAIYA, M.A., ${ }^{1}$ ABDULRAHEEM, A., ${ }^{2}$ IJAIYA, M.A. ${ }^{3}$ AND ABDULLAHI, I.B. ${ }^{1}$

${ }^{1}$ Department of Finance, University of Ilorin, Ilorin, Nigeria

${ }^{2}$ Nigeria Deposit Insurance Corporation, Abuja

${ }^{3}$ Department of General Studies, Federal University of Technology, Minna, Nigeria

\begin{abstract}
Using a time subscript and a difference-in-difference estimator that describes the changes in food crops as a function of changes in ACGS, this paper examines the influence of changes in ACGS loan on food crops output over the years. The result shows that only the initial level of ACGS on food crops has helped moved food security more than the changes experience in recent time. Thus, government should put in place an effective legislation that would establish a reliable ground rules for consistent and equitable application of ACGS and stable macroeconomic policies that would sustained it.
\end{abstract}

Key Words: Agricultural Credit, Food Security

\section{Introduction}

The current interest in food security in Nigeria is hardly surprising because out of the total area of $923,768 \mathrm{~km} / \mathrm{sq}$, Nigeria-land-mass is estimated at $910,768 \mathrm{~km} / \mathrm{sq}$ with about 80 per cent fertile agriculture land-mass made of Altisols, Utisols and Entisols, while Vertisols constitute only 8 per cent (Economy Watch, 2015; Esu, 2005). Apart from the above natural resources, the human resources (estimated at 178.721 Million people by the Economy Watch, 2015) if effectively managed, the nation would be food abundant. However, Saliu and Omotola (2005) noted that with these potentials, Nigeria is till food insecure. This situation is worsened by the protracted crises of Boko Haram in the North East that brought serious hunger to the region and Nigeria as a nation. The International Fund for
Agricultural Development and World Food Programme (IFAD and WFP) (2015) report indicates that hunger still remains an everyday challenge for almost 795million in the world including about 780 million people in developing countries that are chronically under nourished most especially in sub-Saharan Africa where food insecurity is confirmed as a major problem (Okuneye, 2001; Smith et al., 2006; IFC Annual Report online, 2016).

In Nigeria, more than 80 per cent of Nigeria's rural population engages in agriculture between 1963 and 1964, which contributed about 65 per cent of the nation's Gross Domestic Product (GDP). However, the contribution of agriculture, most especially, food crops have been on the decline due to the paucity of agricultural credit. (Iganiga and Unemhilin, 2011; Awe, 2013; 
Zakaree, 2014; Etonihu et al., 2013; Anetor et al., 2016). Since food is vital for the enjoyment of other rights as indicated in the Declaration of Human Rights in 1948 (UN, 1999; Ijaiya, 2016), the Federal Government of Nigeria established the Agricultural Credit Guarantee Scheme (ACGS) in 1977 with a capital base of one hundred million Naira (\#100million) which was later raised to three billion Naira (N3 billion). The scheme, managed by the Central Bank of Nigeria $(\mathrm{CBN})$ guarantees $75 \%$ of credit extension to Nigerian farmers. (CBN, 2013). Whether this Scheme has successfully achieved its objective over the years is yet to be seen. The thrust of this paper therefore is to examine the influence of changes in ACGS loan on food crops output over the years, using time subscript and difference-indifference estimator.

Conceptual Overview: Agriculture and Agricultural Credit: Meaning, Types and Effects

Anyanwu et al. (1997) and Okuneye (2001) define agriculture as involving the cultivation of land, raising and rearing of animals for the purpose of production of food for man, animals and raw materials for industries. It also involves cropping, livestock and forestry, fishing, processing and marketing of these agricultural products. Essentially, agriculture is composed of food production, livestock, forestry and fishing (Ijaiya and Ijaiya, 2005). Ijaiya and Abduraheem (2000) define credit as financial resources obtained at certain period of time with an obligation to repay at a period in accordance with the terms and conditions of the credit. Credit could come from financially able bodies like banks, government or individuals (Pearce, 1992). Agriculture credit on the other hand, is loans extended to farmers for production, storage, processing and marketing of farm products. Such credits can be short, medium or long term depending on its duration. The purpose of agriculture credit may be categorized as livestock production credit, food crop production credit and cash crops production credit depending on the purpose for which the credit is meant (Aku, 1995; CBN, 2004).

Haggblade and Hazell (1989) opined that agricultural credit have a secondary spillover effect on non-farm household via input, labour and output linkages. When farmers face credit constraint, additional credit supply can raise input use, investment and hence output, this is the liquidity effect. Besides, better agricultural credit facilities help farmers smooth out consumption that increase the willingness of risk adverse farmers to take risks and make agriculture investments, this is consumption smoothing effect. Hence, a better agriculture credit may lead to a higher volume of food output, through increased credit in fertilizer purchase, private investment in machines and food crops (Binswanger et al., 1993; Tasie and Offor, 2013; Chisasa and Makina, 2015).

Studies by Trezeciak-Duval (2003) showed that government interventions in form of price control, trade restrictions or "tied" state credits have removed farmers' impediments to profit making and this has improved food production. Zakaree (2014) indicates that ACGS guaranteed loan has a positive and significant impact on domestic food production. Qureshi et al, (1996) also observed that an increase in credit to agriculture by governments can also increase food production and farmers' income. 


\section{Food Security: Meaning, Challenges and Determinants}

Kent (1995) defines food security as the secured access to enough food at all times. Thus, food security is related to the supply of food and individual access to it. Little wonder the Food and Agricultural Organisation (FAO) (2003) defines food security as the availability at all times of adequate world food supplies of basic foodstuffs to sustain a steady expansion and prices. Patel (2013) however argued that food supplies could not be an end in food security chain unless people have access to it, and defines food security as all times people have physical and economic access to sufficient, safe and nutritious food to meet their dietary needs and food preferences for an active and healthy life.(CBN, 2007). This definition has two main elements, first the availability of food, through production, storage or Imports; and second, accessibility of food through income or financial resources to grow it. (Ijaiya, 2016).

IFAD (2007) infers that food security is a combination of two distinct problems namely acquirement and utilization. Acquirement refers to household ability to acquire enough food through production, exchange or transfer. Utilization is the capacity of the household to transform their ability to use the food. Therefore, a household can be said to be food secured only if it is secured in terms of both the acquirements and the utilization of food. Acquirement is constraint by droughts, shipping disruptions, agricultural crop diseases, government actions, fuel shortages, economic instability, climate change, land degradation, and wars (Boeing, 2016). For instance, the India Grows a Grain Crisis (2006) observe that one of the main challenges of food security is water deficits that arises from overpumping of aquifers that result from drought, land degradation through intensive farming that leads to exhaustion of soil fertility; climate change and global warming, etc. (Fiona, 2011).

Discussing the determinants of food security, IFAD (2007) identifies four levels of food security determinants: as (i) the ability to improve and maintain the level of acquirement; (ii) the ability to cope with shocks to acquirement; (iii) the ability to improve and maintain the level of utilization, and (iv) the ability to cope with shocks to utilization. The level of acquirement is described as the endowment set and entitlement mapping. The endowment set is the resources a household owns or over which it had usufructary rights, whether legal or convectional. While entitlement mapping refers to the rate at which the endowment set resources can be converted into food. Thus, endowment set and entitlement mapping determine household ability to acquire food. The ability to acquire food can also be affected by shocks from crop failure, unemployment, higher cost of food, etc. The ability of each household to cope with shocks determines their access to food. Besides coping with shocks, food security level depends on how well this food was utilized. This utilization depends on qualities of preparation and storage of food. For instance, most rural household produce or buy food, store the food for at least a part of the lean season. However, poor storage facilities lead to substantial loss in the quality and the quantity of food. Thus, the efficiency of preparation and storage facilities also determine the household access to food at all times. The forth determinant is the ability to cope with 
shocks of utilization which refers to the metabolism of food by individuals. The illness of a wife for instance can affect the proper utilization of food, thus the availability and the quality of women's health care facilities and a support network to help women in the performance of domestic chores also determinants household access to food. (Luther, 1999; FAO, 2009; Godfray et al., 2010).

Mano et al. (2003) avert that sound strategic grain reserve policies, agricultural development strategies that favours smallholder rural development, soil fertility and more intensive and diverse land use, based on the domestication of indigenous trees to produce high value products, sound macro-economic policies, domestic marketing and pricing policies, and regional trade regulations contribute greatly to food security. (Sanchez and Leakey, 1997).

Cung et al. (1995) study on food security in India shows that many people have become permanent or attached labourers in the rural India of Amrepalle and Shirmpur in order to feed their families, while some tie their stomach with cloth and sleep so that they would not feel hungry.

Agriculture Credit Guarantee Scheme (ACGS) and Food Security in Nigeria: The Trend and Constraints

The Federal Government of Nigeria established the ACGS in 1977 to arrest the problem of food insecurity. (Adetiloye, 2012). However, since food security is reduced to a problem of production and national self-sufficiency in food (Korf and Bauer, 2002), this section discusses the trend of AGCS and food production in Nigeria. This trend as indicated in Table I shows that the percentage of ACGS loan to food production were low between 1978 and 1988 , this is also reflected on total food production between 1978 and 1988 . However, from 1989 to 2015 except for pocket of fluctuations, there has been an increase in credit disbursement to food production, this increase is reflected on total food production for the country in the period. This increase was attributed to the effect of the: enlightenment campaigns adopted by the $\mathrm{CBN}$ to improve credit delivery; National Programme for Food Security (NPFS) in Nigeria sponsored by the Unilateral Trust Fund (UTF) loan of US \$45.2 million to improve food production; construction of several multi-purpose irrigation dams; implementation of various agricultural policies; institutional support programmes on rice, maize, fruits and other food crops; Millennium Development Goals loan on animal traction and hand tools technology loan scheme to farmers; provision of assorted fertilizer to farmers; and various efforts on pests control have all contributed to increase food production. (CBN 2003; 2010; 2012; 2014).

Apart from the above factors that improve food production, agriculture production is constrained in Nigeria by poor credit delivery, even where it is delivered, it does not get to the poor farmers but rather to the rich farmers who divert the loan to other activities that do not support food production (Aku, 1995; Ijaiya and Ijaiya, 2005). This problem is worsened by the civil strife that displaced many people from their homes and farmlands in the North East. Food production is also constrained by poor storage facility, bad governance, and poor infrastructural facilities especially bad road network and electricity. The 
inadequate supply of fertilizer and farming inputs, the time lag between the supply and distribution of agricultural inputs and erratic planting period, bad weather and national disasters such as drought and floods, insects and diseases experienced in some states constrained food production (CBN 1992; 1996; 2012).

Table 1: Agricultural Credit Guarantee Scheme (ACGS), to Food Crops and Total Food Crops Production 1978-2015

\begin{tabular}{|c|c|c|c|c|}
\hline \multirow{2}{*}{$\begin{array}{l}\text { Year } \\
1978\end{array}$} & $\begin{array}{l}\text { Total ACGS } \\
\text { loan }\left(\#^{\prime}(000)\right.\end{array}$ & \multicolumn{2}{|c|}{$\begin{array}{l}\text { Total ACGS loan to } \\
\text { food crops }\left(\#^{\prime}(000)\right.\end{array}$} & \multirow[t]{2}{*}{$\begin{array}{l}\text { Total food crops } \\
\text { Output('000 tones) }\end{array}$} \\
\hline & $11,284.4$ & $2,868.2$ & 51.6 & \\
\hline 1979 & $33,596.7$ & $7,456.1$ & 49.9 & \\
\hline 1980 & $30,945.0$ & $5,176.3$ & 51.1 & \\
\hline 1981 & $35,642.4$ & $7,444.7$ & 52.0 & \\
\hline 1982 & $31,763.9$ & $5,706.4$ & 53.2 & \\
\hline 1983 & $36,307.5$ & $8,202.6$ & 50.3 & \\
\hline 1984 & $25,154.9$ & $3,606.4$ & 55.6 & \\
\hline 1985 & $44,242.1$ & $12,498.0$ & 57.5 & \\
\hline 1986 & $68,417.4$ & $33,405.3$ & 61.8 & \\
\hline 1987 & $102,152.7$ & $56,906.6$ & 49.6 & \\
\hline 1988 & $118,611.0$ & $77,949.9$ & 52.4 & \\
\hline 1989 & $129,300.3$ & $100,013.1$ & 94.4 & \\
\hline 1990 & $98,493.4$ & $79,869.6$ & 100.0 & \\
\hline 1991 & $82,107.4$ & $64,944.8$ & 118.0 & \\
\hline 1992 & $91,953.0$ & $76,260.7$ & 129.6 & \\
\hline 1993 & $80,845.9$ & $70,252.0$ & 133.9 & \\
\hline 1994 & $91,821.1$ & $82,072.4$ & 138.5 & \\
\hline 1995 & $163,938.6$ & $121,067.6$ & 141.9 & \\
\hline 1996 & $243,608.0$ & $171,836.3$ & 150.0 & \\
\hline 1997 & $244,025.2$ & $187,491.6$ & 154.8 & \\
\hline 1998 & $217,699.0$ & $175,764.8$ & 160.0 & \\
\hline 1999 & $246,993.5$ & $204,058.0$ & 165.5 & \\
\hline 2000 & $357,832.0$ & $303,677.0$ & 171.0 & \\
\hline 2001 & $810,821.1$ & $605,525.7$ & 177.1 & \\
\hline 2002 & $1,062,391.8$ & $925,734.7$ & 184.1 & \\
\hline 2003 & $1,894,281.4$ & $1,015,194.6$ & 196.2 & \\
\hline 2004 & $3,308,704.3$ & $1,807,667.7$ & 168.7 & \\
\hline 2005 & $3,066,723.5$ & $2,615,181.1$ & 180.3 & \\
\hline 2006 & $4,263,060.3$ & $3,636,053.7$ & 221.6 & \\
\hline 2007 & $4,425,861.8$ & $3,533,429.7$ & 237.7 & \\
\hline 2008 & $6,721,074.6$ & $4,775,375.7$ & 252.5 & \\
\hline 2009 & $8,349,509.3$ & $5,496,286.2$ & 267.2 & \\
\hline 2010 & $7,740,507.6$ & $5,194,976.1$ & 282.6 & \\
\hline 2011 & $10,189,604.3$ & $6,657,657.2$ & 298.4 & \\
\hline 2012 & $9,706,761.2$ & $5,979,762.9$ & 309.6 & \\
\hline 2013 & $9,424,450.0$ & $5,668,766.6$ & 324.3 & \\
\hline 2014 & $12,997,004.2$ & $6,976,104.0$ & NA & \\
\hline 2015 & $1,441,978.8$ & NA & NA & \\
\hline
\end{tabular}




\section{Methodology \\ Data Source}

Time series data for the period 1978 to 2015 on the total loan provided by the ACGS to food security proxy by the total food crops production in Nigeria were used. Data were obtained from the Central Bank of Nigeria (CBN) Statistical Bulletin for various years.

\section{The Model}

In specifying the model, emphasis is placed on whether the changes on the loans provided by ACGS on food crops production have any significant influence on the changes in food security in Nigeria.

Having established the link, the first equation is formulated as follows:

$$
\mathrm{FS}_{\mathrm{t}}=\mathrm{f}\left(\mathrm{ACGS}_{\mathrm{t}}\right)
$$

Following Barro and Sala (1995), Grootaert et. al, (1995), Ijaiya \& Ijaiya (2005) methods of analysis that uses a time subscript $(t)$ and a difference-inindifference estimator $(\Delta)$, we therefore model the relationship between the changes in food security proxy by food crop production and the changes in the loan provided by ACGS on food security as follows:

$$
\Delta \mathrm{FS}_{\mathrm{t}}=\mathrm{f}\left(\mathrm{ACGS}_{\mathrm{t}}\right)
$$

Equation (2) thus describes the changes in food security as a function of changes in loans provided by ACGS.

The introduction of the initial level of the loan provided by ACGS on food security in Nigeria i.e. $\left(F S_{t}\right)$ into equation (2) therefore gives the following equation:

$$
\Delta \mathrm{FS}_{\mathrm{t}}=\mathrm{f}\left(\Delta \mathrm{ACGS}_{\mathrm{t}}, \Delta \mathrm{ACGS}_{\mathrm{t}}\right)
$$

The transformation of equation (3) into linear equation then becomes:

$\Delta \mathrm{F} S_{t}=\beta_{0}+\beta_{1} A C G S_{t}+\beta_{2} \Delta A C G S+\mathrm{U}(4)$ Where:

$\mathrm{FS}_{\mathrm{t}}=$ the initial level of food security in Nigeria (proxied by food crop production)
$\Delta F S_{t}=\quad$ the changes in the level of food security in Nigeria (proxied by changes in food crop production).

$\mathrm{ACGS}_{\mathrm{t}}=$ the initial level of loans provided by Agricultural Credit Guarantee Scheme on food security (in million Naira)

$\triangle \mathrm{ACGS}_{\mathrm{t}}=\quad$ the changes in the loans provided by Agricultural Credit Guarantee Scheme on food security (in million Naira)

$$
\beta_{0}=\quad \text { the intercept }
$$

$\beta_{\mathrm{I}}$ and $\beta_{2}=$ the parameter estimates that stands for the speed of convergence of the loans provided by $A C G S_{t}$ on food security in Nigeria, with a positive value indicating convergence of total loan provided by $A C G S_{t}$ on food security while a negative value indicates a divergence.

$U=\quad$ the term.

To estimate the model, a multiple regression analysis is used in order to reflect the explanatory nature of the variances. To verify the validity of the model, two major evaluation criteria were used: $(i)$ the a-priori expectation criteria which is based on the signs and magnitudes of the coefficients of the variables under investigation; and (ii) statistical criteria which is based on statistical theory, which in other words is referred to as the First Order Least Square (OLS) consisting of R-square $\left(R^{2}\right), F$-statistic and $t$-test. The R-Square $\left(R^{2}\right)$ is concerned with the overall explanatory power of the regression analysis, the F-statistic is used to test the overall Significance of the regression analysis and the t-test is used to test the significance contribution of the independent variables on the dependent variables (Oyeniyi, 1997; Greene, 2008).

Drawn from the model, the a-priori expectations or the expected pattern of 
behaviour between the dependent variable $\triangle F S_{t}$ and the independent variables $A C G S_{t}$ and $\triangle A C G S_{t}$ are: $A C G S_{t}$ $>0, \triangle A C G S_{t}>\mathrm{O}$. Indicating that an increase in the initial level of loans provide by ACGS on food security and a positive change on the loans provided by $A C G S_{t}$ on food security are expected to increase food security in Nigeria.

\section{Results and Discussion}

The Results of the regression analysis are presented in Table 2

Table 2: Regression Results of ACGS and Food Security in Nigeria

\begin{tabular}{lc}
\hline Explanatory variables & Co-efficient and t-values \\
\hline Intercept & $-12,454.05$ \\
(t) & $(-0.74)$ \\
ACGS & 0.25 \\
(t) & $(11.5)^{*}$ \\
$\Delta$ ACFS, & -0.10 \\
$(\mathrm{t})$ & $(-1.75)$ \\
$\mathrm{R}^{2}$ & 0.88 \\
$\mathrm{~F}$ & 95.2 \\
\hline
\end{tabular}

$\mathrm{t}$-values in Parentheses. ${ }^{*}$ statistically significant at 5 per cent level of significance.

A look at the model shows that it has an $\mathrm{R}^{2}$ of 0.88 which in other words means that 88 per cent variation in the dependent variable $(\Delta \mathrm{FS})$ is explained by the independent variables $\left(\mathrm{ACGS}_{\mathrm{t}}\right.$ and $\triangle \mathrm{ACGS}_{\mathrm{t}}$ ), while the error term take care of the remaining 12 per cent, which are variables in the study that cannot be included in the model because of certain qualitative features. At 5 per cent level of significance, the F-statistic shows that the model is useful in determining the influence of changes in the loans provided by ACGS on food security in Nigeria as the computed F-statistics which is 95.2 is greater than the tabular F-statistics valued at 5.49.

The estimated parameters of the variables (initial level of the loans

\section{Conclusion and Recommendations}

Using a time subscript (t) and difference-in-difference estimator $(\Delta)$ that includes the initial level of the loans provided by ACGS on food security to provided by ACGS on food security and changes in the loans provided by ACGS on food security are positively and negatively related to food crops production respectively. An indication that the initial level of the loans provided by ACGS on food security induces an increase in food security than the changes witnessed in the loans provided by ACGS on food production in Nigeria. By mere prediction, this result implies that at a point of estimate of 100 per cent, a reduction in the loans provided by ACGS on food security would have a cumulative effect in reducing food security in Nigeria by 10 per cent in the following year.

the changes in the loans provided by ACGS on food security, this paper explored the relationship between the changes in the loans provided by ACGS on food security and changes in food 
security in Nigeria. Our findings indicate that the initial level of the loans provided by ACGS on food security has helped improved food security more than the changes experienced in recent times. To improve this, the following policy measures are recommended:

- There is need to build a strong institutional framework for agriculture financing. To achieve this, the country needs an effective legislation that would establish a reliable ground rules for consistent and equitable application of agricultural loans since most of the $A C G S$ loans in recent times hardly get to the farmers.

- Besides, there is need for a wellfunctioning and well-integrated markets for agricultural inputs, (like fertilizer, tractors, harvesters etc) commodities and processed goods to improve food security.

- The government should play an important role in contract enforcement in agricultural development by ensuring timely and just recourse against the failure to meet contract obligations or other abuses in agricultural policies most especially on food production. The existing infrastructural facilities should be improved and a sound macroeconomic policy should be pursued.

- Financial institutions, most especially commercial banks that implement the ACGS funds should be monitored to avert diversion of funds and prompt disbursement of loans.

- Government fight against corruption should be extended to ACGS loans, commercial banks and other agencies in the agricultural sector. The National Assembly should not spare these units in their oversight functions.

- Government should also intensify the war on insurgents so that the millions of people displaced in the North East Nigeria can return to their homes and farms.

\section{References}

Adetiloye, K.A. (2012). Agricultural Financing in Nigeria: An Assessment of the Agricultural Credit Guarantee Scheme Fund (ACGSF) for Food Security in Nigeria. Journal of Economics, 3(1), $39-48$.

Aku, P.S. (1995). Comparative Analysis of NACB and ACGSF Loan Disbursement to Agriculture in Nigeria. Journal of Social and Management Studies, 2: 99-108.

Anetor, F.O., Ogbechie, C., Kelikume, I. and Ikpesu, F. (2016). Credit Supply and Agricultural Production in Nigeria: A Vector Autoregressive (VAR) Approach. Journal of Economics and Sustainable Development, 7(2): 131- 143.

Anyanwu, J.C., Oyefusi, A., Oaikhem H. and Dimowo, F.A. (1997). The Structure of Nigerian Economy (1960-1997). Onitsha: Joanee Educational Publisher.

Awe, A.A. (2013). Mobilization of Domestic Resources for Agricultural Productivity in Nigeria. Australia Journal of Business and Management Research. 2(12): 1- 7.

Barro, A. and Sala I.M. (1995). Economic Growth. London: McGraw Hill Inc.

Binswanger, H.P., Khandker, S.R. and Rosenzweig, C. (1993). How 
Infrastructure and Institutions affect output and investment in India. Journal of Development Economics. 41(2): 337 - 366.

Boeing, G. (2016). How our Neighbourhoods Lost Food, and How They Can Get it Back. Progressive Planning, (Winter), 35 $-37$.

Central Bank of Nigeria (CBN). Annual Report and Statement of Account for the Year Ended (Various Issues), Lagos/Abuja: CBN.

Chisasa, J. and Makina, D. (2015). Bank Credit and Agricultural Output in South Africa: Cointegration, Short Run Dynamics and Causality. Journal of Applied Business Research (JABR), 31(2): 489 - 500. Cung, K., Haddad L., Ramakrishna J., \& Riely F. (1995). Alternative Approaches to Locating the Food Insured, Qualitative and Quantitative Evidence from South India. Washington D.C.: IFRI

Economy Watch (2015). Nigerian Economic Statistics and Indicators. Retrieved from http://www.economicwatch.com/ec onomic-statistics/country/Nigeria.

Esu, I. (2005). Characterisation, Classification and Management Problems of the Major Soil Orders in Nigeria. Text of Inaugural Lecture, University of Calabar, April.

Etonihu, K.I., Rahman, S.A. and Usman, S. (2013). Determinants of access to agricultural credit among crop farmers in a farming community of Nasarawa State, Nigeria. Journal of Development and Agricultural Economics, 5(5): 192 - 196.
FAO (2003). Trade, Reforms and Food Security: Conceptualizing the Linkages. Rome: FAO, UN.

FAO (2009): Declaration of the World Food Summit on Food Security. Rome: FAO, UN.

FAO, IFAD and WFP (2015). The State of Food Insecurity in the World 2015. Meeting the 2015 International hunger targets: taking stock of uneven progress. Rome: FAO, UN.

Fiona, H. (2011). Extreme Weather will strike as climate change takes hold, IPCC Warns. http://www.guardian.co.uk/environ ment/201/nov/18/extreme-weatherclimate-change-ipcc.

Godfray, H.C.F., Beddington, J.R., Crute, I.R., Haddad, L., Lawrence, M., Muir, J. F., Pretty, J., Robinson, S., Thomas, S. M., and Toulmin, C. (2010). Food Security: The Challenge of Feeding 9 Billion People. Science, 327(5967): 812 818.

Green, W.H. (2008). Econometric Analysis. New Jersey: Pearson Prentice Hall.

Grootaert, C; Kanbur, R., and Oh, G. (1995). Dynamics of Poverty-Why Some People Escape and Others Don't: An African Case Study, World Bank Policy Research Working Paper No. 1499.

Haggblade, S. and Hazell, P. (1989). Farm - nonfarm Linkages in Rural sub-Saharan Africa. World Development 17(8), 1173-1201.

IFAD (2007). Food, Poverty and Women: Lessons from Rural Asia, http: www.ifad.org.

IFAD and WFP (2015). The State of Food Insecurity in the World 2015. Meeting the 2015 International 
Hunger Targets, taking stock of uneven progress. Remo: FAO, UN

IFC Annual Report online (2016). Strengthening Food Security in Challenging Places. Retrieved from http://www.ifc.org

Iganiga, B. O. and Unemhilin, D.O.(2011). The Impact of Federal Government Expenditure on Agricultural Output in Nigeria. World Review of Business Research. 2(2): $81-88$

Ijaiya, A.T. (2016). Waste to Wealth: Micro-Livestock Production as a Catalyst for Food (Protein) Security. Text of Inaugural Lecture Series 46. FUT, Minna. October.

Ijaiya, G.T. and Abdulraheem, A. (2000). Commercial Banks Credits to the Agricultural Sector and Poverty Reduction in Nigeria: A Calibration Analysis. Nigerian Journal of Agricbiz and Rural Development, 1(1): 143-157.

Ijaiya, M.A. and Ijaiya, G.T. (2005). The Impact of Agriculture Finance on Agricultural Output in Nigeria, In: Jugale (Ed.) Poverty Globalization and Human Development. New Delhi: Serials Publications.

India Grows a Grain Crisis (2016). Asian Times. July. Retrieved on 13/11/2011

Kent, G. (1995). Aquaculture and Food Security. In PACON (eds.) Proceedings of the PACON Conference on Suitable Aquaculture. (95): $11-14$

Korf, B. and Bauer, E. (2002). Food Security in the Context of Crisis and Conflict: Beyond Continuum thinking. International Institute for Environment and Development.
Luther, T. (1999). The Economics of Global Food Security. Review of Agricultural Economics. 21(4): 466 $-478$

Mano, R., Isaacson, B., and Dardel, P. (2003). .Identifying Policy of Determinants of Food Security Response and Recovery on the SADC Region: The Case of the 2002 Food Emergency; Paper Prepared for the F ANRP AN Regional Dialogue on Agricultural Recovery, Food Security and Trade Policies in Southern Africa Gaborone, Botswana, 26-27 March.

Okuneye, P.A. (2001). Rising Cost of Food Prices and Food Insecurity in Nigeria and its Implication for Poverty Reduction, CBN Economic and Financial Review, 39, 4.

Oyeniyi, T.A. (1997). Fundamental Principles of Econometrics, Lagos: Cader Publication.

Patel, R. (2013). Food Sovereignty is next big idea. Financial Times.

Pearce, D.W. (Eds.) (1992). Dictionary of Modern Economics. Macmillan.

Qureshi, S., Nabil, I. and Faaruquee, R. (1996). Rural Finance for Growth and Poverty Alleviation. World Bank Policy Research Working Paper No. 1593.

Saliu, H.A. and Omotola, J.S. (2006). Food Insecurity and National Question in Nigeria, In: Saliu H. A., et. al. (Eds). The National Question and Some Selected Topical Issues on Nigeria, Unilorin: FBSS

Sanchez, P.A. and Leakey, R.P.B. (1997). Land Use Transformation in Africa: Three Imperatives for Balancing Food Security with Natural Resource Conservation, European Journal of Agronomy, 7: $15-23$ 
Smith, L.C., Alderman, H. and Aduyaom, D. (2006). Food Insecurity in SubSaharan Africa: New Estimates from Household Expenditure Surveys, IFRI Report No. 146.

Tasia, C.M. and Offor, U.S. (2013). Effects of International Fund for Agricultural Development (IFAD) Credit Supply on Rural Farmers in River State, Nigeria. Journal of Poverty, Investment and Development, 1: $65-70$.

Trzeciak-Duval, A. (2003). Agriculture Finance and Credit Infrastructure-
Conditions. Policies and Channels Institute of Agricultural Economics, Czech, 3, 106-112.

United Nations (UN) (1999). The Right to adequate food. Committee on Economics, Social and Cultural Rights. Geneva: United Nation

Zakaree, S.S. (2014). Impact of Agricultral Credit Guarantee Scheme Fund (ACGSF) on Domestic Food Supply in Nigeria. British Journal of Economics, Management and Trade. 48(8): $1273-1284$. 